\title{
Consumer insights on prepackaged Cheddar cheese shreds using focus groups, conjoint analysis, and qualitative multivariate analysis
}

\author{
K. C. Speight, A. N. Schiano, W. S. Harwood, and M. A. Drake* \\ Department of Food, Bioprocessing and Nutrition Sciences, Southeast Dairy Foods Research Center, North Carolina State University, \\ Raleigh 27695
}

\section{ABSTRACT}

This study established attractive attributes and drivers of purchase for prepackaged Cheddar cheese shreds. Seven focus groups of Cheddar cheese shred consumers $(\mathrm{n}=61)$ were conducted to probe consumer beliefs regarding packaging, ingredients, label claims, and applications of prepackaged Cheddar cheese shreds. Subsequently, an online survey was developed utilizing the key attributes from the focus groups. The survey (n $=1,288$ ) included maximum difference scaling, Kano questions, and adaptive choice-based conjoint analysis. Additionally, 9 different commercial Cheddar cheese shreds varying in color, shred thickness, brand, and price were selected for a follow-up qualitative multivariate analysis to gain further consumer insight on attribute importance. Consumers $(\mathrm{n}=13)$ were provided with commercial packages of shreds to evaluate over a 4-week period. Consumers journaled their likes and dislikes after use of each cheese shred and subsequently participated in a final 2.5 -h focus group and projective mapping exercise. Consumers placed highest importance on price, followed by nutrition claims, color, sharpness, thickness, and label claims. Four consumer clusters were identified from conjoint utility scores. One consumer cluster exhibited preference for valueadded features such as nutrition claims and brand, and another consumer cluster placed importance on shred color, whereas the other 2 groups were driven primarily by price. The qualitative multivariate analysis results confirmed the focus group and survey results: meltability, orange color, lack of clumps, ability to reseal the bag, and desirable "Cheddar" flavor were also preferred Cheddar shred qualities.

Key words: Cheddar cheese shreds, consumer liking, conjoint analysis

Received December 25, 2018.

Accepted March 23, 2019.

*Corresponding author: mdrake@ncsu.edu

\section{INTRODUCTION}

In 2017, retail cheese sales in the United States exceeded $\$ 23$ billion, with projected sales of $\$ 25$ billion by 2022 (Mintel Group Ltd., 2018). Cheddar cheese accounted for $29 \%$ of cheese produced in the United States in 2017, second only to Mozzarella (ADPI, 2018). Convenience, flavor, authenticity, and freshness are crucial to American shoppers (Engwall, 2015). Prepackaged Cheddar cheese shreds have grown in popularity and demand because of their convenience and perceived benefits, such as adding extra protein and flavor to dishes.

Consumer preferences for Cheddar cheese have been extensively studied and include flavor and texture (Young et al., 2004; Caspia et al., 2006; Drake et al., 2008). Despite the growing consumer focus on prepackaged convenience products, fewer studies have focused specifically on prepackaged Cheddar cheese shreds. Flavor is presumably important for Cheddar cheese shreds as well as their block counterparts, although previous studies, to our knowledge, have not addressed this issue. Texture and performance may play an even larger role in consumer perception of Cheddar cheese shreds, as cheese shreds are frequently used in hot dishes (Singh et al., 2003; Ni and Guansekaran, 2004). Published studies on cheese shreds have focused on instrumental performance measurements such as melt rate, tack energy, and rheological properties (Guinee et al., 2000; Childs et al., 2007). Established sensory texture and performance attributes for Cheddar cheese shreds include stretchability, meltability, fracture, amount of crumbles, surface smoothness, shred length, uniformity of shreds, shred-to-shred adhesiveness, visual perception of oiliness, and residual oiliness during shred handling (Serrano et al., 2004, 2005). Instrumental measures of cheese texture attributes can correlate with perceived sensory properties, and these attributes may influence consumer liking (Drake et al., 1999; Rogers et al., 2009).

The appearance of Cheddar cheese shreds, such as color or visual powdery surface coating, may also in- 
fluence consumer purchase habits because other factors, such as flavor and performance, are not evident before consumption. Color plays an important role in consumer acceptance of Cheddar cheese (Singh et al., 2003; Singh, 2006; Wadhwani and McMahon, 2012). Size and length of cheese shreds, which affect melt properties and appearance in meals, are other key visual attributes of prepackaged Cheddar cheese shreds (Ni and Guansekaran, 2004). Packaging elements, such as bright colors and appealing images, are correlated with consumer liking of Cheddar cheese (Murray and Delahunty, 2000). Other extrinsic attributes, such as health/nutrition and sourcing conditions, may also influence consumer purchase (Swientek, 2017; Tarver, 2017).

Multiple data collection types are essential to paint a clear picture of which attributes drive consumer perception of a product. Focus groups have been extensively used to investigate a variety of dairy products including drinkable yogurts (Thompson et al., 2007b), chocolate milk (Thompson et al., 2007a), and Gouda cheese (Jo et al., 2018). Online surveys allow collection of quantitative and qualitative data from a large number of consumers and may use a variety of techniques including conjoint analysis, Kano model analysis, and maximum difference scaling (MaxDiff; McLean et al., 2017; Harwood and Drake, 2018).

Conjoint analysis mimics real-world purchasing scenarios by requiring consumers to make "trade-offs" between product concepts (Orme, 2014). Conjoint analysis has been applied to determine consumer preferences for both extrinsic and intrinsic product attributes of sour cream (Jervis et al., 2012), sandwich bread (Jervis et al., 2014), fresh tomatoes (Oltman et al., 2014), and protein beverages (Oltman et al., 2015). Although conjoint analysis estimates the overall importance of each attribute to a holistic product concept, MaxDiff scaling, sometimes referred to as "best-worst" scaling, allows direct comparison of individual attribute/ level combinations (Lynch, 1985; Hein et al., 2008). Respondents are presented with sets of items and asked to choose the "best" and "worst" item from each set (Louviere and Woodworth, 1990; Harwood and Drake, 2018). Kano model analysis approaches consumer sentiments about product attributes by assessing their benefit to the consumer in response to the degree in which they are present (Kano et al., 1984). Kano model results have been correlated with conjoint utility scores and can be considered a qualitative complement to the data derived from conjoint results (Kim et al., 2013; Hubbard et al., 2016; Harwood and Drake, 2018).

Qualitative multivariate analysis (QMA) is a composite qualitative approach consisting of a home usage test, downloading session (post-usage focus group), and projective mapping exercise with product consumers (Beckley et al., 2012). It is a unique approach to capture consumer insights and allows researchers to discover connections between product attributes and consumerassigned value (Beckley et al., 2012). Previous QMA studies on foods include cottage cheese (Drake et al., 2009), ewe milk (Barcenas et al., 2004), and citrus juices (Nestrud and Lawless, 2008). To our knowledge, previous studies have not established extrinsic attributes that drive consumer choice for prepackaged Cheddar cheese shreds. The objective of this study was to characterize consumer perceptions and preferences for prepackaged Cheddar cheese shreds. To accomplish this goal, we conducted focus groups, an online survey, and QMA.

\section{MATERIALS AND METHODS}

\section{Experimental Overview}

The study consisted of 2 parts. In the first part, seven 1.5-h focus groups with consumers of prepackaged Cheddar cheese shreds were conducted. An online survey was conducted to quantify the findings of the focus groups and to determine the decision-making processes that influenced purchase of prepackaged Cheddar cheese shreds. The survey used adaptive choicebased conjoint (ACBC) analysis, Kano analysis, and MaxDiff scaling. In the second part, a QMA study was conducted to investigate how consumers perceived differences between Cheddar cheese shreds when extrinsic information was available. Institutional Review Board for Human Subjects (IRB) exemption was obtained from North Carolina State University IRB before tests.

\section{Focus Groups}

Seven 1.5-h focus groups were conducted to establish consumer perception and to identify desirable attributes for prepackaged Cheddar cheese shreds. Selfreported frequent (2-3 times per week) prepackaged Cheddar cheese shred consumers $(\mathrm{n}=61 ; 20 \%$ men, 80\% women; $19-64$ yr, approximately 8 per group) who were also primary household shoppers participated. All consumers were recruited from an online database of more than 10,000 consumers in the Raleigh/Durham, North Carolina, area maintained by the Sensory Service Center at North Carolina State University. Panelists were selected based on inclusion criteria and answers to open-ended questions regarding Cheddar cheese shred usage. A moderator facilitated discussion through the use of a moderator guide (Figure 1). Focus groups were audio- and video-recorded for subsequent reference. During the focus group, notes were taken by 


\section{Brief Introduction}

- Moderator - Guidelines and purpose.

- Each respondent - Name and favorite cheese.

\section{Focus Area 1 - Shredded Cheddar Cheese Purchasing Factors}

- Why are you purchasing shreds?

- What forms do you purchase?

- What factors influence your purchase?

- Can shreds be artisan? Which brands?

III. Focus Area 2 - Shredded Cheese Packaging

- What catches your attention?

- What do you look for in the package?

\section{Focus Area 3 - Shredded Cheese Ingredients}

- Do you ever look at the ingredients label?

- What are the key ingredients?

- Is color indicative of quality? What is the ideal color? What is the ideal color for Cheddar shreds?

- Ingredient list discussion - What is the purposelfunction of each ingredient?

\section{Focus Area 4-Shredded Cheese Label Claims}

- Fat percentage

- Sodium

- Cholesterol

- Health Claims

- How important are each of these claims: Organic, recombinant bST-free, made with milk from animals not treated with antibiotics/hormones/steroids, locally produced, all natural, family owned, cruelty free, gluten free, non-GMO, high protein, high calcium, lactose-free, low cholesterol, low fat/fat free, reduced sodium?

\section{Focus Area 5 - Shredded Cheese Applications}

- When and in what application do you use shredded cheese?

- What physical characteristics of shreds make them more desirable to cook with?

- How would you describe the importance of cheese shred performance?

\section{Wrap-up}

- Summarize

- Final comments - Before we leave, is there anything you would like to add that was not mentioned?

Figure 1. Moderator guide for Cheddar cheese shred focus groups. GMO = genetically modified organism.

2 observers remotely through a video feed to minimize distractions to panelists. Upon completion of the focus group, panelists were compensated with a gift card for their participation.

\section{Online Survey}

An online survey was designed using Lighthouse Studio (version 9.5.3, Sawtooth Software, Orem, UT).
Data collected from focus groups were used to identify key sensory attributes to develop the online questionnaire (Thompson et al., 2007a; Raz et al., 2008). Consumers were recruited from 12 online databases in the United States containing over 17,000 consumers maintained by the Sensory Service Center at North Carolina State University. Additional consumers were recruited through word-of-mouth and Facebook advertising campaigns. Demographics questions at the start of the sur- 
vey were used to screen consumers. All consumers who completed subsequent survey sections reported having no allergies to dairy products and reported purchase or consumption of prepackaged Cheddar cheese shreds at least once every 3 mo. Survey sections included: 5-point agreement questions, check-all-that-apply (CATA) with purchase factors, 5-point importance questions, MaxDiff scaling, Kano analysis, and ACBC. Consumers were asked 14 agreement questions regarding Cheddar cheese shred perception on a 5 -point scale from disagree

Table 1. Attributes and levels used for adaptive choice-based conjoint (ACBC) analysis

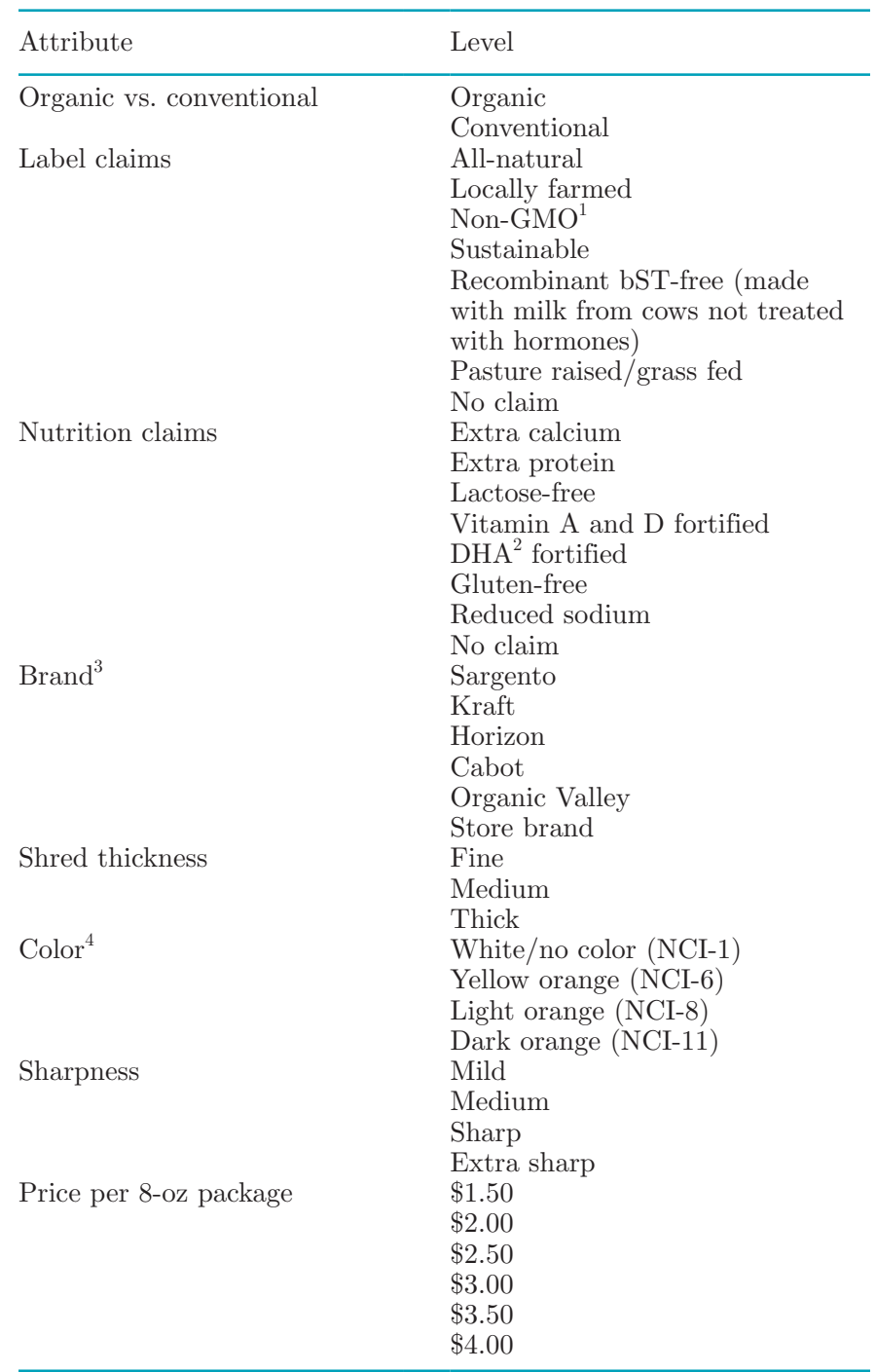

${ }^{1}$ Genetically modified organism.

${ }^{2}$ Docosahexaenoic acid.

${ }^{3}$ Sargento Foods Inc., Plymouth, WI; Kraft Foods, Chicago, IL; Horizon Organic, Broomfield, CO; Cabot, Waitsfield, VT; Organic Valley, La Farge, WI.

${ }^{4}$ Color is from the National Cheese Institute (NCI) Cheese Color Standards (Nelson-Jameson Company, Marshfield, WI). Swatches can be seen in Figure 2. completely to agree completely. Consumers were then provided a list of 35 attributes and asked to select all that influenced their purchase of prepackaged Cheddar cheese shreds. A MaxDiff exercise was then conducted. The MaxDiff exercise included 30 attributes and was designed as 19 sets of best-worst questions, with 5 randomly displayed attributes per set. Each respondent was asked to select the "most important" and "least important" items out of each set to their purchase of Cheddar cheese shreds. Each item was seen at least 3 times. Kano questions were subsequently asked. Respondents answered questions in both a constructive form (e.g., "A prepackaged Cheddar cheese shred that is store brand") and a reductive form (e.g., "A prepackaged Cheddar cheese shred that is NOT store brand"). Possible responses were "I like it," "I expect it," "I am neutral," "I can tolerate it," and "I dislike it" (Riviere et al., 2006).

An ACBC survey was designed with attributes and levels easily understood by consumers. The ACBC consisted of a build-your-own task followed by a screening task and tournament task. A total of 8 attributes were used, with 2 to 8 levels per attribute (Table 1). Levels for the color attribute were displayed as the verbal name of the color along with a color swatch from the National Cheese Institute (NCI) Cheese Color Standards (Nelson-Jameson Company, Marshfield, WI; Figure 2). The single build-your-own task at the start of the conjoint exercise was used to pattern products relevant to respondents for the subsequent screening task (Orme, 2014). Fourteen screening tasks with 4 product concepts each were presented; each attribute was present in all product concepts. Possible responses to each product concept were "a possibility" or "won't work for me" (Cunningham et al., 2010; Jervis et al., 2012). Five "unacceptable" questions and 4 "must-have" questions were built in through the survey. The screening task was followed by a 10-question choice task tournament section. A maximum of 20 product concepts were brought into the tournament section, with 3 concepts per choice task (Hubbard et al., 2016).

\section{QMA}

Thirteen self-reported frequent (2-3 times per week) consumers of prepackaged Cheddar cheese shreds (8 women, 5 men; 25-60 yr; primary shoppers) were recruited from the North Carolina State University Sensory Service Center database. The QMA consisted of 3 parts: a home usage test of selected Cheddar shreds, a focus group, and a projective mapping (PM) exercise (Beckley et al., 2012).

Each participant was provided with 9 commercial Cheddar cheese shred packages (all $>3$ mo from expira- 
White/no color (NCI-1)

\section{Yellow orange (NCI-6)}

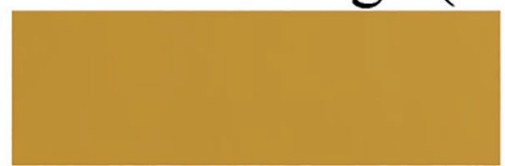

\section{Light orange (NCI-8)}

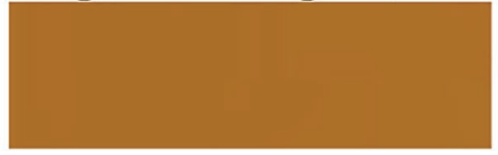

\section{Dark orange (NCI-11)}

Figure 2. National Cheese Institute (NCI) Cheese Color Standards (Nelson-Jameson Company, Marshfield, WI).

tion date) of varying sizes $(6,12$, or 8 oz) over the course of a 4 -wk period. Each consumer received 2 to 3 packages of shreds at the beginning of each week. Panelists were provided with written instructions and an online diary link accessible by computer or smart device (e.g., phone, tablet; Compusense Cloud, Guelph, ON, Canada). Products were provided branded in commercial packaging with price and weight information available. Consumers were instructed to use the shreds however they wanted, write a few sentences describing their experience with each product (i.e., what they liked, disliked, noticed), assign an overall liking score (9-point hedonic scale; 1 = "dislike extremely, 2 = "like extremely"), and upload 2 photos of the meal or snack they prepared with the cheese shreds. Participants were instructed to try each product in a meal or application that they were familiar with at least once but were not required to use the product again if they did not want to. There was an enforced rest time of $24 \mathrm{~h}$ between sample evaluations.

At the end of the 4-wk period, participants returned to the university for a 2.5-h focus group and PM exercise. Consumers were provided a copy of their online diary entries before the start of the discussion, including uploaded pictures of the products, price, and weight for each sample. Each commercial shred sample was discussed individually, followed by a group discussion of all samples. A moderator facilitated the discussion but allowed panelists to direct the flow of discussion rather than following a strict moderator guide (Beckley et al., 2012). Audio and video of the downloading session were recorded for subsequent reference. Notes were taken by 2 observers remotely through a video feed to minimize distractions to panelists. Notes included themes, key words, and specific purchase drivers mentioned by twothirds or more of consumers.

Following the downloading session, a PM exercise was conducted on iPads using Compusense Cloud (Risvik et al., 1994; Savidan and Morris, 2015). During the PM exercise, panelists were asked to consider how similar or dissimilar each of the 9 cheese shreds was from each other. They were instructed to place each sample on the blank map on the screen in proximity to other samples based on their perceived similarities and differences - the more similar the samples, the closer they are in proximity. Panelists were then instructed to tag each sample with descriptors. Panelists were provided with 9 descriptors (orange color, white/pale color, sharp flavor, mild flavor, melts well, does not melt well, like packaging, like appearance of shreds, and crumbly/powdery) but could also add their own attributes. Panelists were allowed to assign up to 8 tags on a sample.

\section{Statistical Analysis}

Note-based analysis was used to identify key points from focus groups. To reduce personal bias, consumer responses were discussed and compiled by both the moderator and the 2 observers. Key points mentioned by two-thirds or more of participants in all focus groups were used for development of questions for the subsequent online survey. All analyses were performed at $95 \%$ confidence $(P<0.05)$. Statistical analyses were conducted with XLSTAT version 2017.19.5 (Addinsoft, Paris, France). Five-point scale agreement questions were analyzed with Kruskal-Wallis one-way ANOVA with Dunn's nonparametric multiple pairwise comparisons. Frequencies of responses to CATA questions were analyzed using chi-squared analysis. Kano results were evaluated using the model proposed by Kano et al. (1984). Correspondence analysis was used to analyze categorized Kano model results for clarifying product sentiments not captured by traditional Kano model classification (Lillestøl, 1991). Count data from Kano analysis were subjected to correspondence analysis in XLSTAT to further characterize the consumer clusters derived from the conjoint exercise. Root likelihood values were determined for each respondent from the conjoint survey, and respondents that received a root 
likelihood value of 0.333 or lower were removed to ensure that quality data were collected and reported. Hierarchical Bayesian estimation was used to calculate importance and utility scores for MaxDiff and conjoint results. Utility scores were standardized using a zerocentered difference method for ease of interpretation (Childs and Drake, 2009). Analysis of variance with means separation using Fisher's least significant difference test was applied to importance and utility scores. Cluster analysis of individual utility scores was performed using Euclidean distance and Ward's linkage to categorize similar respondents into groups. Chi-squared analysis was applied to demographic data to determine differences among clusters. Multiple correspondence analysis was conducted to visualize how demographics and clusters were characterized.

Multiple factor analysis was used to analyze projective mapping data (XLSTAT) (Cruz et al., 2013). Frequencies of descriptor tags on samples from the PM exercise were included as supplementary multiple factor analysis variables. Consumer-generated descriptor tags were included in the analysis only if added by more than $10 \%$ of consumers. A value diagram was generated from responses from the downloading session using a procedure for value diagrams outlined by Moskowitz et al. (2012). Consumers were asked what they looked for most when shopping for prepackaged Cheddar cheese shreds to establish the main elements (or anchors) for the value diagram. These factors are tangible, yet very general. Then, the consumers provided examples of specific experiences with prepackaged Cheddar cheese shreds to generate descriptors for each element. The elements were placed next to each other on the value diagram to show connections between elements, and descriptors were placed underneath the elements. Chisquared analysis was also applied to determine differences among cheeses in tag usage.

\section{RESULTS}

\section{Focus Groups}

Key attributes mentioned most frequently by consumers included sharpness, color, price, fat, melt, packaging, powder, ingredients, and quality. Price was important to almost all participants and was often noted to be the most important purchase factor. Flavor/sharpness and meltability were considered important attributes by all participants. Less frequently cited purchase factors included package weight, shelf life, and label claims.

Most participants said they would not purchase a product again if it performed (melted) poorly. Color affected Cheddar cheese shred liking for almost all participants. Most participants preferred light or dark orange shreds. White shred color was associated with all-natural products, whereas bright yellow or orange shreds were considered "not natural." For many consumers, health and label claims were not a key factor when making purchase decisions. Most participants expected cheese shreds to be "unhealthy" (high in fat and salt) and were not willing to sacrifice flavor and meltability for health benefits (such as reduced fat or sodium). The most frequently purchased fat contents were $2 \%$ and full fat.

The top 3 negative attributes were visible powder coating, clumping, and sweating. Some participants noted that they used hand-shredded Cheddar for special occasions, noting the powder coating on prepackaged Cheddar shreds and concern for recipe quality. In all groups, an overwhelming majority of participants stated that they did not like prepackaged Cheddar cheese shreds that had visible powder, clumps, or both in the package. Most consumers were unsure what the visible powder consisted of, with some consumers suggesting the powder was an antibiotic, preservative, anti-clumping agent, or finely ground dried cheese. The majority of consumers $(>80 \%)$ did not know what ingredients formed the powdery coating.

Participants also stated that packaging influenced their purchase of Cheddar cheese shreds. Participants preferred packages with attractive designs and transparent windows for viewing shreds before purchase. Shreds with a further expiration date from the back of the display case were an indicator of freshness to some consumers. Most participants used prepackaged Cheddar cheese shreds for convenience and to add flavor to food. A few participants indicated that they would be willing to pay more for artisan cheese shreds if they were entertaining guests or making a special recipe.

\section{Survey Demographics}

A total of 1,288 consumers participated in the survey. Of these respondents, $21.0 \%$ were male and $79.0 \%$ were female. The majority of participants identified as Caucasian (75.9\%) followed by African American (12.7\%). Of the respondents, $85.5 \%$ had at least some college education. An even distribution of ages was reported: $27.7 \%$ of respondents were 18 to $30 \mathrm{yr}, 31.0 \%$ were 31 to $45 \mathrm{yr}$, and $41.2 \%$ were 46 to $64 \mathrm{yr}$. An even distribution of yearly incomes was also self-reported $(<\$ 15,000$ to $>\$ 100,000)$.

\section{Purchase Habit and Agreement Questions}

Most respondents (57.5\%) consumed prepackaged Cheddar cheese shreds weekly, whereas $28.5 \%$ consumed prepackaged Cheddar cheese shreds at least 
twice a month. Most of those surveyed (76.1\%) purchased prepackaged Cheddar cheese shreds most often at a standard grocery store although $16.6 \%$ purchased prepackaged Cheddar cheese shreds most often at a discount grocery store.

For the 5-point agreement questions, most participants agreed that Cheddar cheese shreds were convenient (92.4\%), tasted great (78.0\%), and were a good source of calcium (72.3\%). Under $10 \%$ of respondents indicated Cheddar cheese shreds were a high-end product, low-end product, or artisan product, suggesting that consumers view shredded cheese as a universal commodity rather than a specific product that can be "luxury" or "budget." Although $31.2 \%$ of consumers agreed that prepackaged Cheddar shreds were more processed than block cheese, only $19.8 \%$ agreed that prepackaged shreds had more ingredients than block cheese. Just $9.6 \%$ of consumers agreed prepackaged shreds were "all natural." Despite indications that Cheddar cheese shreds may be perceived as a commodity item, only $17.9 \%$ of consumers agreed that prepackaged shreds were the same in flavor and melt regardless of brand, indicating that consumers perceived differences among brands of Cheddar shreds. A CATA question was also presented, asking participants which qualities affected their purchase of prepackaged Cheddar cheese shreds. Of the attributes listed, the majority of participants selected price (83.2\%), flavor/sharpness (68.6\%), expiration date $(64.1 \%)$, package size $(62.0 \%)$, thickness of shred (54.9\%), and weight/amount of cheese in bag $(52.3 \%)$.

\section{Adaptive Choice-Based Conjoint Analysis}

No respondents from the ACBC exercise had a root likelihood value below 0.333 , so all responses were used. Importance scores differentiate the importance of attributes, whereas utility scores explain the attractiveness of levels within an attribute (Orme, 2014). Utility score estimates from hierarchical Bayesian analysis are reported as zero-centered differences. Higher utility scores indicate levels that are more attractive to consumers. Negative utility values do not necessarily indicate that a level is unattractive but rather less attractive than those with a positive utility value within the same attribute (Orme, 2014).

Based on importance scores, price was the most important attribute for consumers, followed by nutrition claims, color, sharpness, shred thickness, label claims, brand, and organic $(P<0.05$; Table 2$)$. Within the price attribute, the lower the price, the higher the utility score $(P<0.05$; Table 3$)$. Within the nutrition claims attribute, lactose-free and gluten-free had the lowest utility scores, whereas extra calcium, vitamin A and D fortified, no claim, and extra protein had the highest utility scores $(P<0.05$; Table 3$)$. This result suggests that these consumers preferred label claims on shredded cheese, perhaps because label claims indicate a higher value product for the same price, but did not have strong opinions on individual label claims. Similar opinions were voiced during focus groups.

Yellow orange (NCI-6) had the highest utility of the colors followed by light orange (NCI-8), dark orange (NCI-11), and white/no color (NCI-1) $(P<0.05$; Table $3)$. These results were consistent with previous studies that suggest that consumers generally expect a certain degree of orange color for Cheddar cheese (Partridge, 2009; Foegeding, 2015; Colantuono and Mikkola, 2017). However, as indicated in focus groups, shreds that are too dark orange may lead consumers to be suspicious of whether the shreds are "real cheese." Sharp flavor scored the highest utility for sharpness, followed by extra sharp, medium, and mild $(P<0.05)$, which was consistent with focus group discussions. For shred thickness, the overall population gave medium thickness the highest utility $(P<0.05)$. This result was consistent with focus group results. During focus groups, many consumers indicated they purchased both thick

Table 2. Mean importance scores for attributes evaluated by adaptive choice-based conjoint analysis clustered by utility

\begin{tabular}{|c|c|c|c|c|c|}
\hline Attribute & $\begin{array}{l}\text { Total population } \\
\quad(\mathrm{n}=1,288)\end{array}$ & $\begin{array}{l}\text { Cluster } 1 \\
(\mathrm{n}=474)\end{array}$ & $\begin{array}{l}\text { Cluster } 2 \\
(\mathrm{n}=304)\end{array}$ & $\begin{array}{l}\text { Cluster } 3 \\
(\mathrm{n}=253)\end{array}$ & $\begin{array}{l}\text { Cluster } 4 \\
(\mathrm{n}=257)\end{array}$ \\
\hline Price per 8-oz package & $34.1^{\mathrm{A}}$ & $16.9^{\mathrm{d}}$ & $54.2^{\mathrm{a}}$ & $38.9^{\mathrm{b}}$ & $37.5^{\mathrm{c}}$ \\
\hline Nutrition claims & $16.5^{\mathrm{B}}$ & $19.7^{\mathrm{b}}$ & $11.4^{\mathrm{c}}$ & $11.1^{\mathrm{c}}$ & $22.1^{\mathrm{a}}$ \\
\hline Sharpness & $10.6^{\mathrm{C}}$ & $12.8^{\mathrm{a}}$ & $7.7^{\mathrm{c}}$ & $9.6^{\mathrm{b}}$ & $10.8^{\mathrm{b}}$ \\
\hline Shred thickness & $9.0^{\mathrm{D}}$ & $11.2^{\mathrm{a}}$ & $6.6^{\mathrm{c}}$ & $9.3^{\mathrm{b}}$ & $7.2^{\mathrm{c}}$ \\
\hline Label claims & $7.8^{\mathrm{E}}$ & $10.9^{\mathrm{a}}$ & $5.1^{\mathrm{c}}$ & $6.7^{\mathrm{b}}$ & $6.2^{\mathrm{b}}$ \\
\hline
\end{tabular}

${ }^{\mathrm{A}-\mathrm{G}}$ Different letters within this column indicate significant differences among attributes within the total population $(P<0.05)$.

${ }^{\mathrm{a}-\mathrm{d}}$ Different letters within rows for the cluster 1 to 4 columns indicate significant differences in attributes among clusters $(P<0.05)$. 
Table 3. Mean utility scores ${ }^{1}$ for attributes evaluated in the adaptive choice-based conjoint analysis clustered by utility

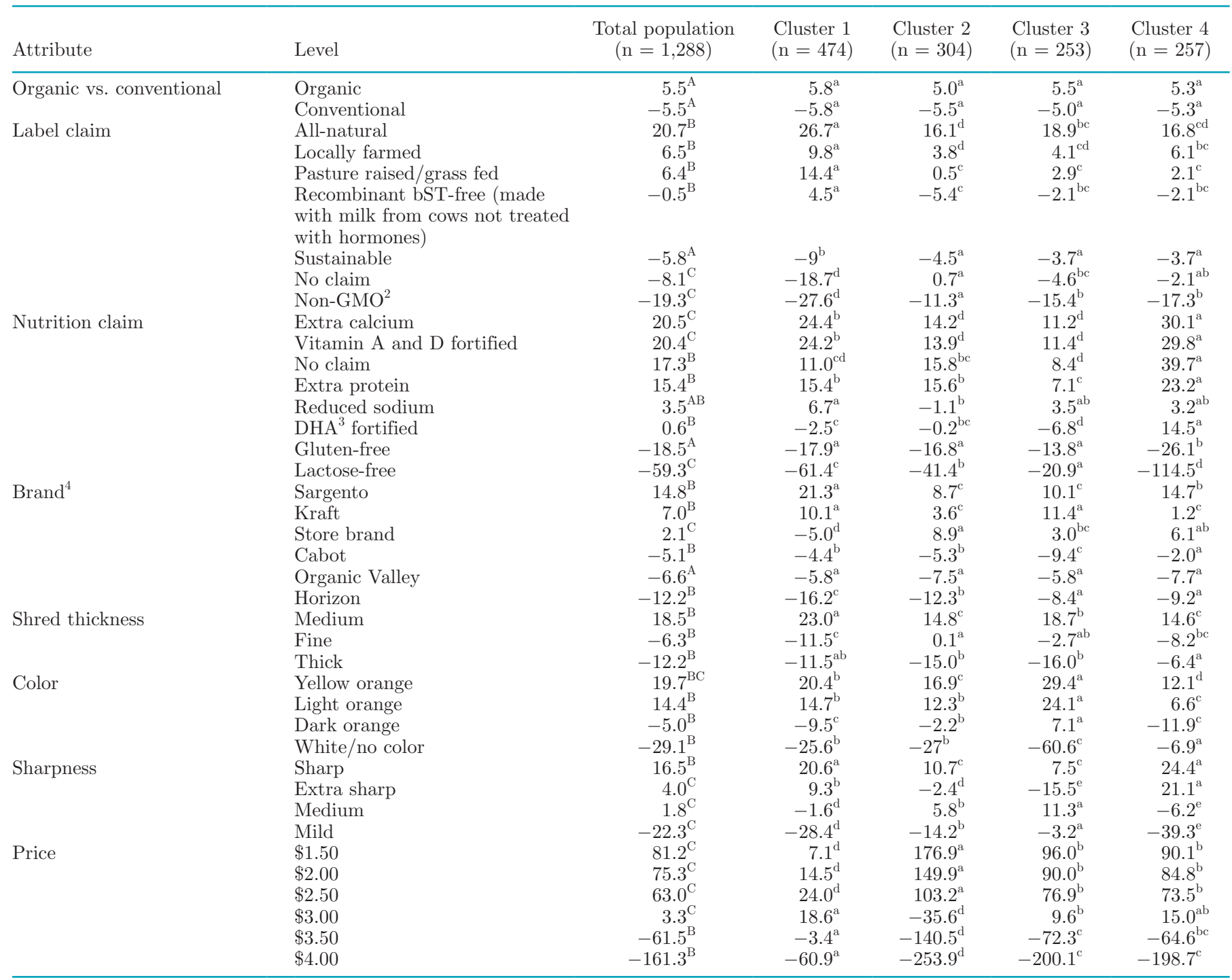

\footnotetext{
${ }^{\mathrm{A}-\mathrm{C}}$ Different letters in this column indicate significant differences within each attribute for the total population $(P<0.05)$.

${ }^{\mathrm{a}-\mathrm{e}}$ Different letters in columns 2 to 5 indicate significant differences between clusters and total population for each level $(P<0.05)$.

${ }^{1}$ Zero-centered utility values for levels within attributes.

${ }^{2}$ Genetically modified organism.

${ }^{3}$ Docosahexaenoic acid.
}

${ }^{4}$ Sargento Foods Inc., Plymouth, WI; Kraft Foods, Chicago, IL; Horizon Organic, Broomfield, CO; Cabot, Waitsfield, VT; Organic Valley, La Farge, WI.

and thin shreds depending on the intended application. Without a specific application specified, it is likely consumers would gravitate to a "middle ground" option.

For label claims, all-natural had the highest utility followed by locally farmed and pasture raised (scored at parity), recombinant bST-free, sustainable, no claim, and non-GMO $(P<0.05$; Table 3$)$. Within the brand attribute, Sargento (Plymouth, WI) was generally favored by consumers followed by Kraft (Chicago, IL), store brand, Cabot (Waitsfield, VT), Organic Valley
(La Farge, WI), and Horizon (Broomfield, CO) $(P<$ 0.05). Despite the 2 organic brands (Horizon and Organic Valley) scoring lowest utility, organic was favored over conventional $(P<0.05)$ in the organic status attribute. However, organic versus conventional was the lowest importance claim overall as determined by conjoint analysis $(P<0.05)$, suggesting that consumers may like the idea of organic versus conventional cheese shreds but that this attribute, for most consumers, does not significantly affect purchases. 


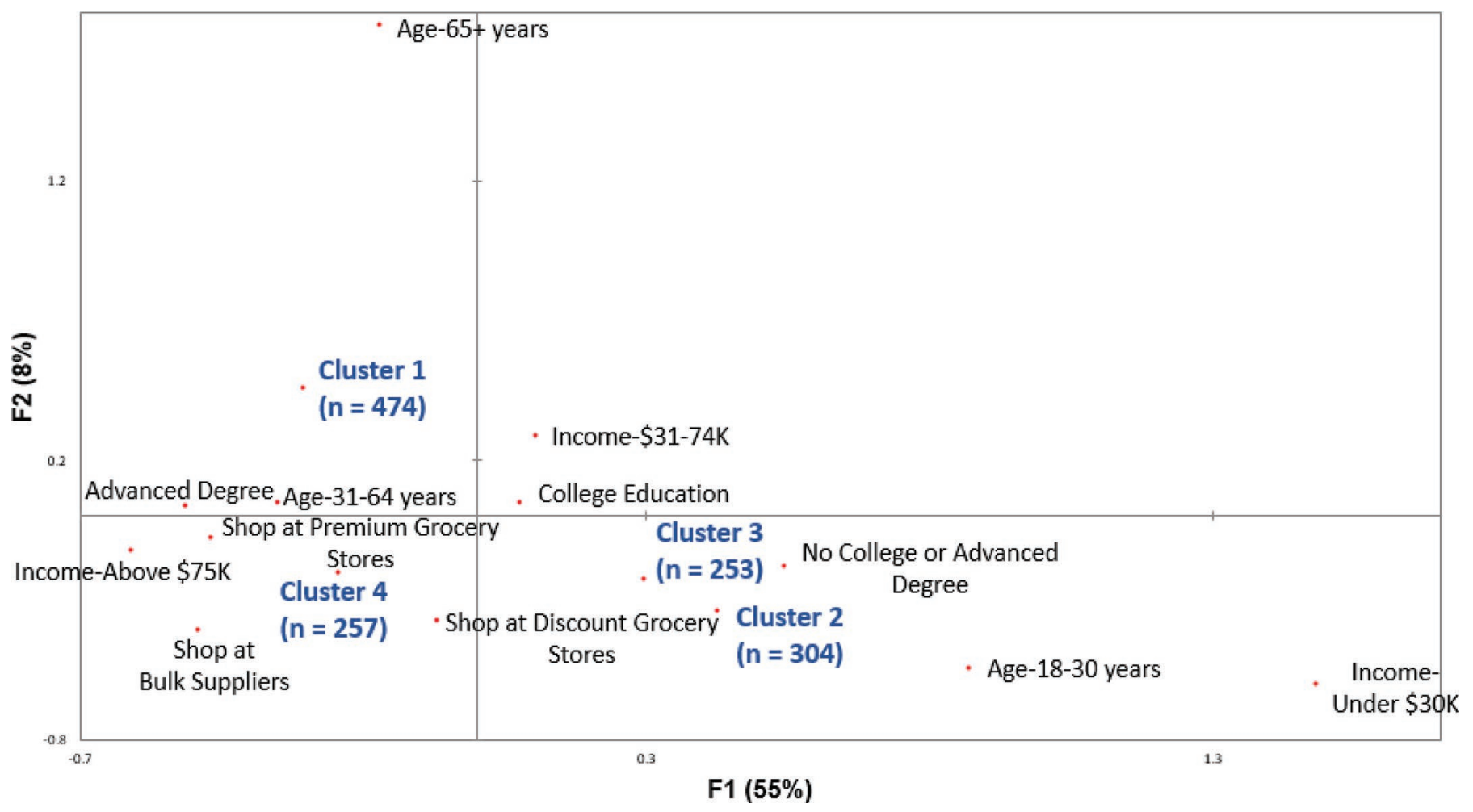

Figure 3. Multiple correspondence analysis of demographic data of survey participant clusters.

Raw utility scores were subjected to k-means clustering, and 4 consumer clusters were identified. Demographic differences were noted among consumer clusters (Figure 3$)$. Cluster 1 consumers $(\mathrm{n}=474)$ were the least price-driven (value-added shoppers) and were characterized by consumers who were older (31-64 yr), very educated (advanced degree), shopped at premium grocery stores, purchased name-brand products, and were concerned mostly with sharpness, shred thickness, and label claims. Cluster $2(\mathrm{n}=304)$ consumers were younger (18-30 yr), the most price-driven based on conjoint importance scores, and used cheese shreds as an everyday commodity item. Cluster 3 consumers $(\mathrm{n}=253)$ were family shoppers, were evenly represented in all age ranges with the exception of 18 to 30 yr, tended to have mid-range incomes, and were the most concerned about color. Cluster 4 consumers (n $=257$ ) were 31 to $64 \mathrm{yr}$, educated (advanced degree), and price-driven based on conjoint importance scores. These consumers also placed the highest importance score for nutrition claims.

\section{MaxDiff Scaling}

The MaxDiff scaling results are shown in Table 4 . Flavor/sharpness was ranked more important than any other attribute $(P<0.05)$. Price and shelf life were the next most important attributes $(P<0.05)$, followed by package size/weight and fat content $(P>0.05)$. Meltability/product performance, thickness of shred, highquality packaging/resealable zippers, and absence of visible powder/coating on the shreds completed the top 10 attributes ranked most important. The 3 attributes ranked least important were lactose-free, gluten-free, and DHA (docosahexaenoic acid)-fortified, claims that are rarely found on commercial cheese shreds. These results suggest that there is a group of consumers who are willing to pay more for desired flavor, as price ranked second overall $(P<0.05)$. These results were consistent with the findings from the focus groups, CATA questions, agreement questions, and ACBC, particularly the emphasis on flavor and price.

\section{Kano Questions}

Kano results are presented in Table 5. Kano classifications included the following: attractive - typically unexpected by consumer and resulting in increased satisfaction when fulfilled; must-have expected by consumer and leading to dissatisfaction if not fulfilled; one-dimensional - a linear relationship exists between fulfillment and satisfaction; rejecter - consumers are 
indifferent if the feature is not present and dissatisfied if it is present; and indifferent - consumer is not interested or affected by the feature, whether it is present or absent. Flavor/taste was a one-dimensional attribute for all consumer clusters, as expected. Price was a onedimensional attribute (lower price leads to higher consumer liking) for all consumer clusters except cluster 1, consistent with the conjoint results labeling cluster 1 as the least price-sensitive cluster. Meltability/product performance was a must-have for all clusters except cluster 2, for which the attribute was one-dimensional. Conjoint results indicated that cluster 2 consumers were the most price-driven and viewed prepackaged Cheddar shreds as an everyday commodity item. Unlike consumers in other clusters, these consumers may be willing to compromise on flavor and performance to obtain a better price, and thus are more satisfied with Cheddar shreds that perform better. Consumers in the other, less price-sensitive clusters may simply avoid purchasing cheese shreds that do not perform well, and thus expect good meltability/performance as a basic requirement of their Cheddar shreds. "Melts well" was a one-dimensional attribute for all consumer clusters with the exception of cluster 4 , who considered it a musthave. Meltability/product performance is an important and expected attribute of Cheddar shreds, but differing Kano results for meltability/product performance and "melts well" indicate that consumers believe attributes other than melt influence product performance.

Sharp flavor was considered attractive across all consumer clusters, consistent with focus groups, conjoint analysis, and MaxDiff results, whereas chemical ingredient names and stuck-together shreds were considered rejecters for all clusters. Both thick and thin shreds were considered attractive for all consumer clusters except cluster 1, who were indifferent to all shred size attributes (Table 5). The attractiveness of both thick and thin shreds is consistent with focus group

Table 4. Mean maximum difference (MaxDiff) scaling scores for purchase of prepackaged Cheddar cheese shreds $(\mathrm{n}=1,288)$

\begin{tabular}{lc}
\hline & $\begin{array}{c}\text { Average } \\
\text { MaxDiff score } \\
\text { (scaled to } 100)\end{array}$ \\
Reasons for buying prepackaged Cheddar cheese shreds & $8.9^{\mathrm{a}}$ \\
\hline Flavor/sharpness & $8.4^{\mathrm{b}}$ \\
Price & $8.2^{\mathrm{b}}$ \\
Expiration date on the cheese & $6.6^{\mathrm{c}}$ \\
Package size/weight & $6.4^{\mathrm{d}}$ \\
Fat content (made from fat-free/skim, 1\%,2\%, whole-fat/regular milk) & $6.0^{\mathrm{e}}$ \\
Meltability/product performance & $5.4^{\mathrm{f}}$ \\
Thickness of shred & $4.9^{\mathrm{g}}$ \\
The package has a high-quality resealable zipper & $4.8^{\mathrm{g}}$ \\
No powder/coating on shredded cheese & $4.8^{\mathrm{g}}$ \\
Ingredients label & $3.9^{\mathrm{h}}$ \\
Brand & $3.7^{\mathrm{i}}$ \\
All-natural & $2.9^{\mathrm{j}}$ \\
Recombinant bST-free & $2.8^{\mathrm{j}}$ \\
Amount of cheese that is visible through the package & $2.5^{\mathrm{k}}$ \\
Calcium content & $2.3^{\mathrm{k}}$ \\
Protein content & $2.1^{\mathrm{b}}$ \\
Cruelty free & $2.0^{\mathrm{l}}$ \\
Sodium content & $1.8^{\mathrm{m}}$ \\
Sustainable & $1.7^{\mathrm{m}}$ \\
Pasture-raised/grass-fed & $1.7^{\mathrm{m}}$ \\
Dark (orange) color & $1.6^{\mathrm{m}}$ \\
Pale (orange-yellow) color & $1.4^{\mathrm{n}}$ \\
Non-GMO & $1.3^{\mathrm{n}}$ \\
Organic & $1.1^{\mathrm{O}}$ \\
Locally produced & $0.8^{\mathrm{p}}$ \\
White color & $0.8^{\mathrm{p}}$ \\
Cheese region/origin & $0.5^{\mathrm{q}}$ \\
Gluten-free & $0.4^{\mathrm{qr}}$ \\
Lactose-free & $0.3^{\mathrm{r}}$ \\
\hline
\end{tabular}

${ }^{\mathrm{a}-\mathrm{r}}$ Attributes that do not share a letter are statistically different $(P<0.05)$. A larger mean indicates a more important attribute.

${ }^{1}$ Genetically modified organism.

${ }^{2}$ Docosahexaenoic acid. 


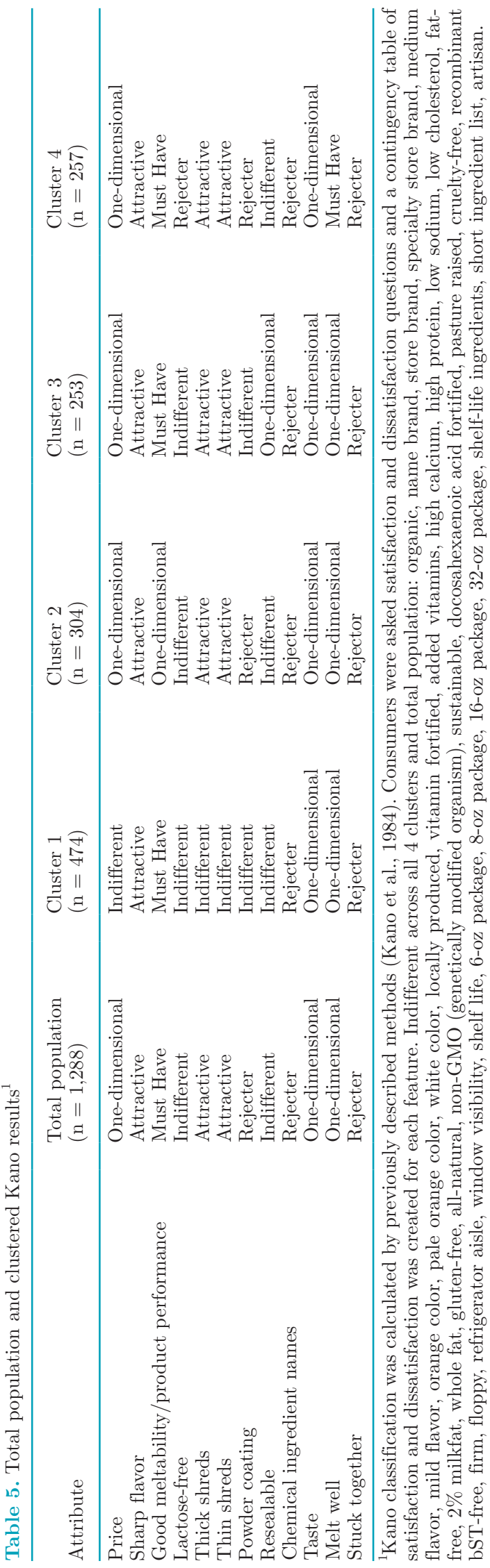

and conjoint results, indicating that consumers prefer both types (thick and thin) of shreds but for different purposes. Powder coating was a rejecter for clusters 1 and 3. Consumers in clusters 2 and 4, however, were indifferent to the powder coating, consistent with their focus on price and willingness to compromise on other product attributes.

Previous studies with other dairy products and other foods suggest that consumers are looking for flavor, natural products, and low prices (Felix, 2009; Engwall, 2015; Saltmarsh, 2015; Mintel Group Ltd., 2018). One study on reduced- and low-sodium Cheddar and Mozzarella cheeses showed that consumers were not willing to sacrifice flavor for claims such as reduced sodium (Ganesan et al., 2014), consistent with Kano results in this study. Due to the "clean label" movement (a consumer shift toward labels containing only "natural" ingredients or lacking the presence of "artificial" or "chemical"-sounding ingredients), consumers are looking for products with no additional additives or preservatives (Saltmarsh, 2015; Foegeding, 2015; Colantuono and Mikkola, 2017).

\section{QMA}

Consumer diaries identified both positive and negative attributes for prepackaged Cheddar cheese shreds, which were consistent with focus group and survey results. Frequently mentioned positive attributes included good price (mentioned 42 times in diaries), nice aroma (41 times), melts well during cooking (90 times), sharp/ good flavor (69 times), no visible powder (4 times), and no visible clumping (4 times). Frequently mentioned negative attributes included too expensive (mentioned 41 times in diaries), no aroma/bad aroma (13 times), shreds did not melt well or thickened or dried out during cooking (poor performance; 25 times), too greasy (5 times), too sharp or too mild flavor (24 times), visible powder ( 8 times), chemical-sounding ingredients (2 times), and clumping (2 times).

Diaries indicated that participants prepared both hot and cold food items. Consumers used Cheddar shreds as both an ingredient and a topping for recipes and consumed shreds at all mealtimes. Commonly prepared foods included salads, eggs, mac and cheese, tacos, chicken, and dips. Most consumers chose to use shreds in a variety of ways during the home usage test, indicating that consumers find prepackaged Cheddar shreds a versatile option. Following the home usage test, consumers discussed key values of prepackaged Cheddar cheese shreds during the 2-h downloading session. The key values to consumers for Cheddar shreds were performance, nutrition and ingredients, quality, price, packaging, convenience, and versatility of usage 
(Figure 4). Positive performance-related attributes mentioned during the downloading session were sharp flavor, meltability, spreadability, moistness, not stuck together, and color. Positive packaging-related attributes mentioned during the downloading session were aesthetic design, clear labels, resealable zipper, and big visibility window. Positive nutrition- and ingredientsrelated attributes included high protein, high calcium, greater than $2 \%$ fat, and no chemical ingredient names. Overall, participants in the QMA placed highest importance on price and performance, consistent with ACBC, MaxDiff, Kano, and focus group results.

The QMA participants also addressed negative experiences with the cheese shreds. Negative attributes included visible powder coating, sweaty cheese, poor meltability/performance (no melt or too greasy when melted), not enough flavor, and too high price. Most participants $(>80 \%)$ agreed that the price was reasonable for most of the products (price ranged from $\$ 0.28$ to $\$ 0.92 / \mathrm{oz}$ ) with the exception of 1 name brand and 2 organic brands. The 8-oz packages ranged from $\$ 2.29$ to $\$ 4.00 /$ package, the 6 -oz package was $\$ 5.54 /$ package, and the 12 -oz package was $\$ 6.99 /$ package.
Figures 5 and 6 show the average projective map and descriptor tags generated by the QMA consumers for the Cheddar shreds that they evaluated. The QMA consumers differentiated products by color and cost ( $\mathrm{x}$ axis) and product performance (meltability and flavor) (y-axis). Store brands and Kraft were associated with low cost, orange color, and low performance (inability to melt, brown/bubble, or crisp properly in cooking applications, poor flavor). Premium brands (Sargento and Cabot) were associated with good performance. Organic cheeses (both white) were associated with high cost but varying performance levels.

Consumers assigned descriptor tags to mapped cheeses (Figure 6). Price-related attributes were the most common user-added descriptor tags. Sharp Cheddar cheeses were associated with both good and poor performance. Store brands were associated with bland packaging, whereas premium brands were associated with attractive packaging. More aged cheeses will have a lower melting quality than mild cheeses; however, the age of sharp cheeses can vary greatly as there is currently no industry standard for cheese age labels. Consistent with focus groups, consumers in the QMA

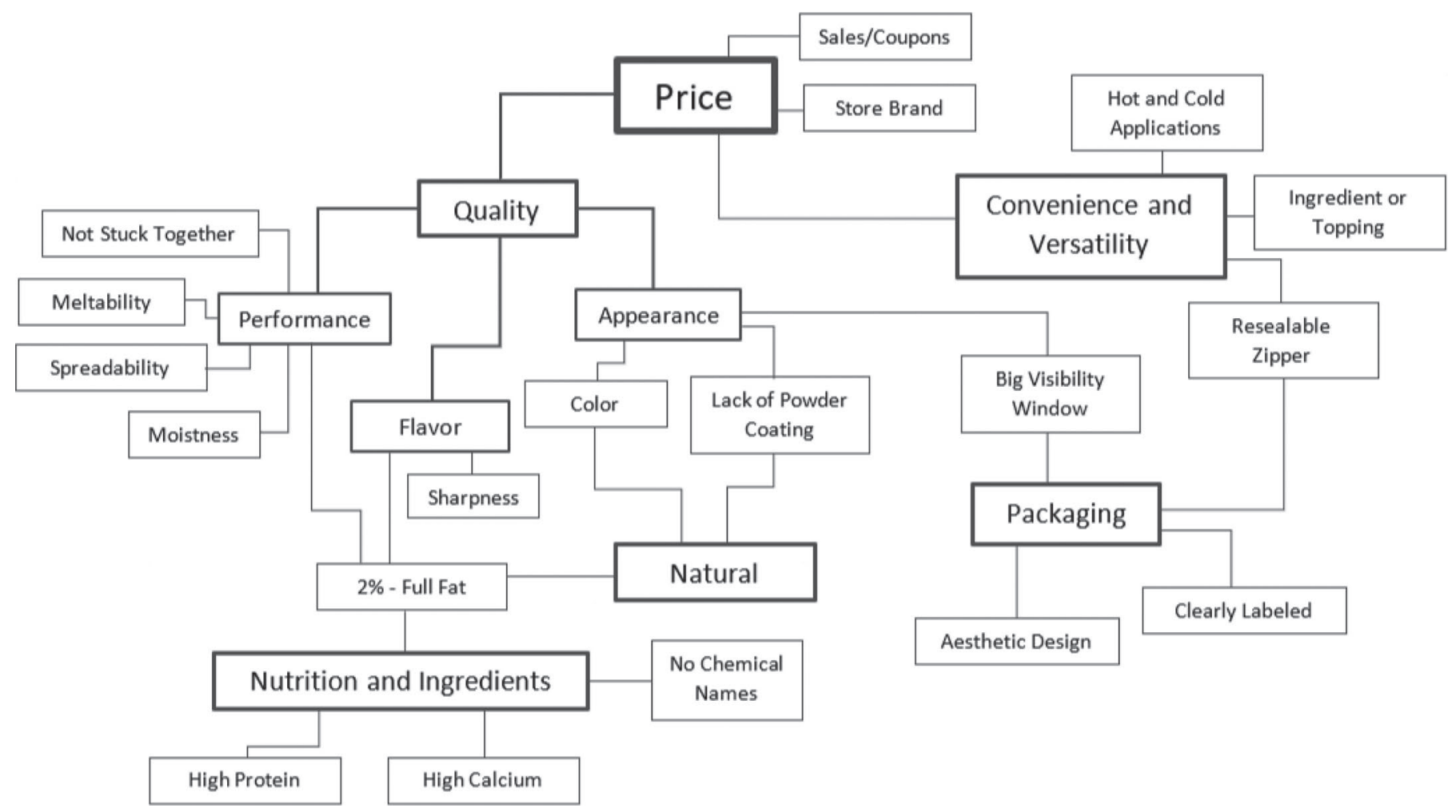

Figure 4. Value diagram based on consumer responses from qualitative multivariate analysis downloading session. Consumers were asked to list most attributes in prepackaged Cheddar cheese shreds. Attributes were agreed on by $>80 \%$ of participants and were positive. Larger text and bolder lines around boxes indicate greater attribute importance based on frequency of responses. 
study wanted both sharp flavor and good meltability and believed that some sharp cheese shreds fulfilled that expectation whereas others did not.

\section{DISCUSSION}

Consistent trends were observed across the different consumer research methods utilized. The importance of price in MaxDiff, Kano, and ACBC results was consistent with focus groups and QMA as well as previous studies with cheese (Solheim and Lawless, 1996; Childs and Drake, 2009). Taste and price were the 2 most important attributes identified by MaxDiff, were one-dimensional attributes in Kano analysis, key ideas in focus groups and the QMA downloading session, and key differentiators for projective maps. Although conjoint analysis did not directly address flavor, price was the most important attribute among respondents. Meltability was also repeatedly identified as a key factor of purchase for Cheddar cheese shreds. Even though cheese shreds are considered an everyday commodity item, many consumers still expect a high-quality product.

Flavor/sharpness was ranked higher than price by MaxDiff. Because flavor is a major factor in consumer liking of Cheddar cheese, it is not surprising that consumers of prepackaged Cheddar cheese shreds consistently wanted shreds with full fat and regular sodium content, suggesting that performance and flavor outweigh any potential health benefits from reduced fat or sodium. Previous studies on Cheddar and Mozzarella cheeses have also established that consumers are not willing to sacrifice flavor for claims such as reduced sodium or lower fat (Bryant et al., 1995; Childs and Drake, 2009; Ganesan et al., 2014). Jervis et al. (2012) evaluated the key choice attributes of sour cream through conjoint surveys and found that consumers placed highest importance on fat content followed by price and brand.

In this study, premium brands were often associated with higher quality cheese shreds; however, brand was not a key purchase driver identified by any method

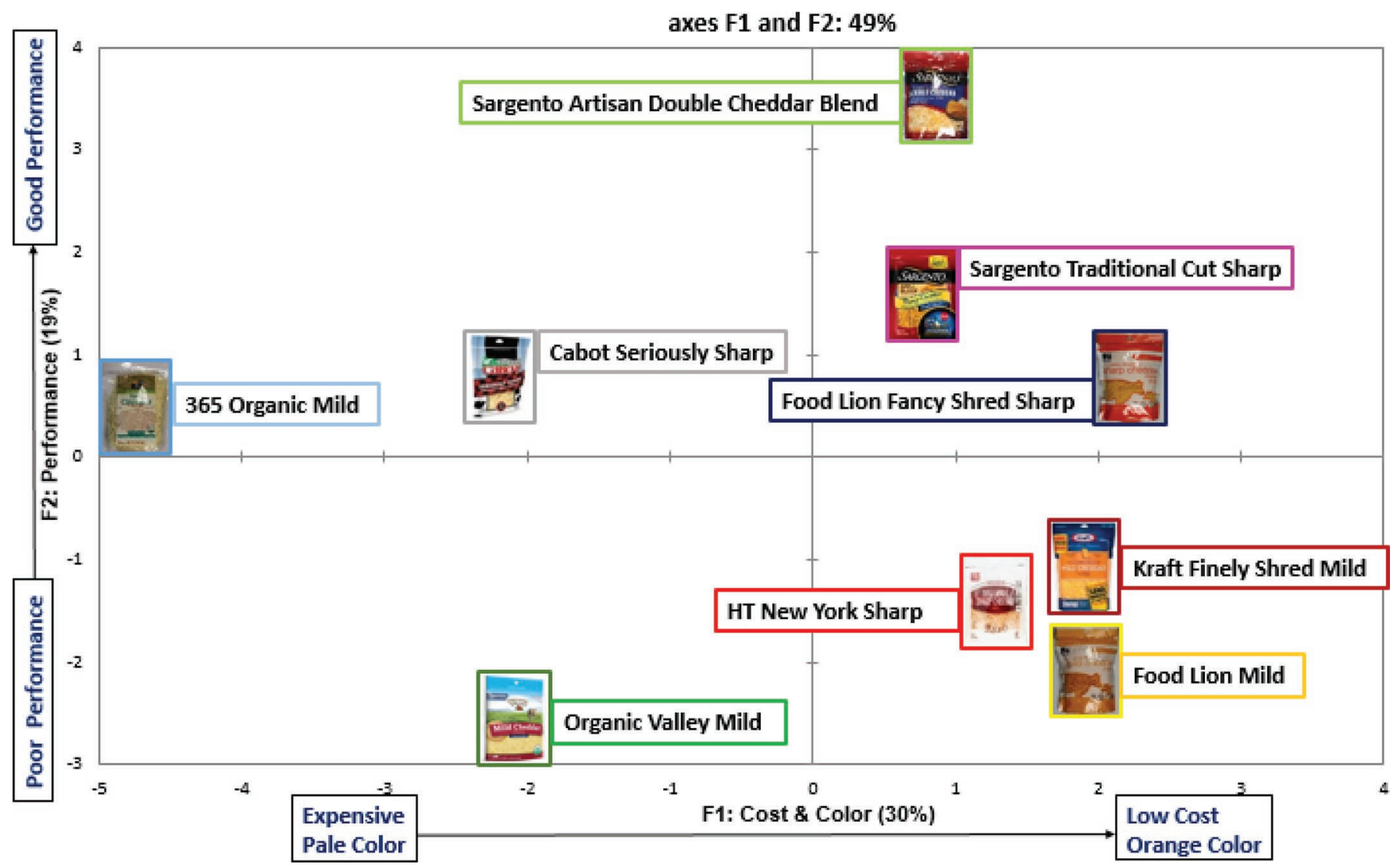

Figure 5. Average projective map from qualitative multivariate analysis consumers $(\mathrm{n}=13)$ for Cheddar cheese shreds using multiple factor analysis (MFA). Sargento Foods Inc., Plymouth, WI; Kraft Foods, Chicago, IL; Horizon Organic, Broomfield, CO; Cabot, Waitsfield, VT; Organic Valley, La Farge, WI; Food Lion, Salibury, NC; Harris Teeter, Matthews, NC; Whole Foods (365), Austin, TX. 
used. Calvo Porral and Levy-Mangin (2016) reported that the affordable prices of private-label brands positively influenced consumer loyalty, consistent with the study by Kumar and Steenkamp (2007) that suggested that the main attribute and primary benefit consumers seek from private label products is an affordable price.

Shred thickness was one of the top 10 attributes identified via MaxDiff, as well as an attractive attribute identified by Kano analysis. However, consumers did not place much importance on shred thickness in the conjoint analysis, and medium shreds had the highest utility scores out of the 3 shred levels. This result supports QMA and focus results, where consumers stated that they prepared a variety of meals with Cheddar cheese shreds. Although consumers may have preferences regarding the thickness of shred used in specific meals, in general, consumers do not believe shred thickness affects the quality of prepackaged shreds.

Powder coating on shreds was a rejecter for consumers in the Kano portion as well as in MaxDiff, focus groups, and QMA results. Shreds that clumped together were also considered a Kano rejecter and identified as a source of dissatisfaction in the QMA. To the industry, these 2 sources of dissatisfaction form a paradox, because powdery anti-caking agents are applied to shredded cheese to prevent clump formation and to help with meltability (Barringer and Sumonsiri, 2015). Manufacturers must be cautious to apply only enough anti-caking agent to prevent serious clumping while keeping the visual powder levels low enough so as to not alarm consumers. Further research is needed to determine the effect of anti-caking agents on consumer liking of prepackaged cheese shreds.

Color was also important to consumers based on focus group, MaxDiff, ACBC, and QMA results. Color was ranked third among $\mathrm{ACBC}$ attribute importance scores, with yellow orange having the highest utility followed by light orange, dark orange, and white/no color. The MaxDiff and ACBC results also demonstrated that consumers expected a certain degree of orange color in a Cheddar cheese. From focus group and QMA discussions, there seemed to be an association with lightercolored Cheddar cheese and a more "natural" product, which was attractive to consumers. The expectation of some orange color presents another interesting challenge for the dairy industry because consumers expect a certain degree of orange color (annatto) and place higher value on "natural" products. However, annatto cannot be labeled as "natural"; even though it is a natural colorant, it is not naturally found in Cheddar cheese (it is an additive to cheese milk to provide the characteristic orange color).

Extrinsic attributes may also affect consumer acceptability of prepackaged Cheddar cheese shreds. The QMA and focus group consumers felt vaguely positive about label claims in general, as the presence of claims added value to the shreds by making the consumers "feel good" about their health or the health of others,

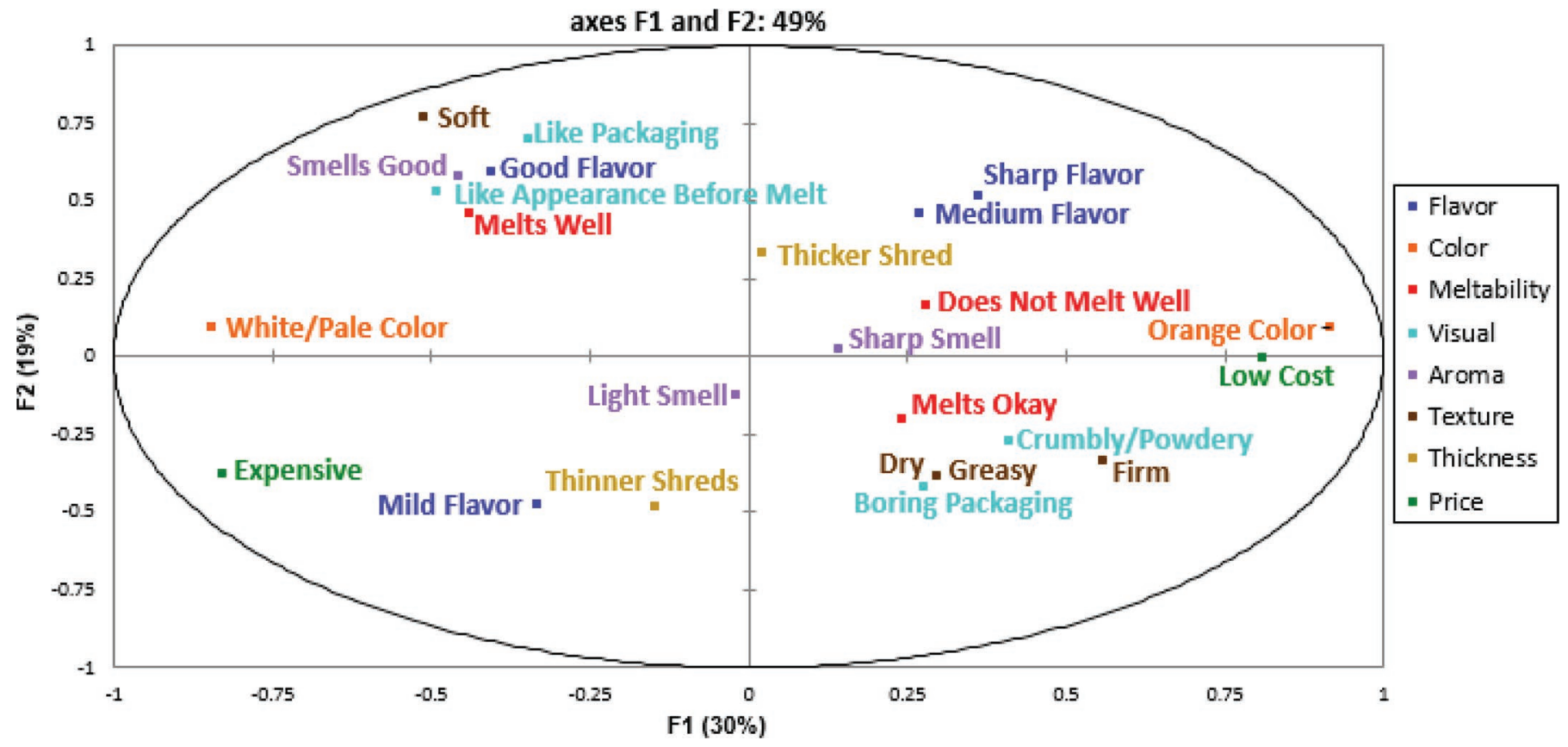

Figure 6. Correlated product descriptors from projective mapping tags from qualitative multivariate analysis consumers $(\mathrm{n}=13$ ) for Cheddar cheese shreds using multiple factor analysis. 
animals, or their community. Hubbard et al. (2016) evaluated the influence of extrinsic attributes on consumer acceptance of cottage cheese and found that specific label claims such as "excellent source of calcium (>10\%)" were more attractive to consumers than "low sodium" or "extra creamy" and that an "all-natural" claim was more appealing than "organic." These results were consistent with the results described in the current study with cheese shreds. Although consumers preferred "natural" products, they expressed no strong preference for organic shredded Cheddar over conventional. Consumers noted that they looked for claims that they expected to find in cheese (such as calcium and protein) and stayed away from claims they were not expecting (such as lactose- and gluten-free). During the conjoint exercise, claims that consumers would not expect on cheese (lactose-free and gluten-free) had lower utility scores than claims commonly found on cheese (extra calcium, vitamin A \& D fortified, and extra protein); "lactose-free" also had the lowest MaxDiff score and was consistent with the focus group, Kano (cluster 4), and QMA results.

\section{CONCLUSIONS}

Prepackaged Cheddar cheese shreds are an everyday item to consumers, with price being a primary driving factor for purchase. However, we identified a "value added" consumer group that is willing to pay more for flavor and nutrition. Flavor and meltability were consistently important and attractive attributes, with high value placed on bold/sharp flavor and high performance/meltability. Consumers consistently wanted shreds with regular fat and sodium content, suggesting that performance and flavor outweigh potential health benefits. Although "all natural" was important to consumers, color was still a key aspect for Cheddar cheese shreds with most consumers expecting some degree of orange color.

\section{ACKNOWLEDGMENTS}

Funding was provided in part by Dairy West (Meridian, ID) and the National Dairy Council (Rosemont, IL). The use of trade names does not imply endorsement or lack of endorsement by those not mentioned.

\section{REFERENCES}

ADPI (American Dairy Products Institute). 2018. 2017 Dairy products utilization and production trends. ADPI, Elmhurst, IL.

Barcenas, P., F. J. P. Elortondo, and M. Albisu. 2004. Projective mapping in sensory analysis of ewes milk cheeses: A study on consumers and trained panel performance. Food Res. Int. 37:723-729.
Barringer, S. A., and N. Sumonsiri. 2015. Electrostatic coating technologies for food processing. Annu. Rev. Food Sci. Technol. 6:157169.

Beckley, J. H., D. Paredes, and K. Lopetcharat. 2012. Qualitative multivariate analysis. Pages 100-121 in Product Innovation Toolbox: A Field Guide to Consumer Understanding and Research. WileyBlackwell, Ames, IA.

Bryant, A., Z. Ustunol, and J. Steffe. 1995. Texture of cheddar cheese as influenced by fat reduction. J. Food Sci. 60:1216-1219.

Calvo Porral, C., and J. Levy-Mangin. 2016. Food private label brands: The role of consumer trust on loyalty and purchase intention. Br. Food J. 118:679-696.

Caspia, E. L., P. C. Coggins, M. W. Schilling, Y. Yoon, and C. H. White. 2006. The relationship between consumer acceptability and descriptive sensory attributes in cheddar cheese. J. Sens. Stud. 21:112-127.

Childs, J. L., C. R. Daubert, L. Stefanski, and E. A. Foegeding. 2007. Factors regulating cheese shreddability. J. Dairy Sci. 90:2163-2174.

Childs, J. L., and M. A. Drake. 2009. Consumer perception of fat reduction in cheese. J. Sens. Stud. 24:902-921.

Colantuono, F., and M. Mikkola. 2017. Consumer insight and approaches in new dairy products development. Pages 404-419 in Advances in Dairy Products. John Wiley \& Sons Ltd., Chichester, UK.

Cruz, A. G., R. S. Cadena, W. F. Castro, E. A. Esmerino, J. B. Rodrigues, L. Gaze, J. A. F. Faria, M. Q. Freitas, R. Deliza, and H. M. A. Bolini. 2013. Consumer perception of probiotic yogurt: performance of check all that apply (CATA), projective mapping, sorting and intensity scale. Food Res. Int. 54:601-610.

Cunningham, C. E., K. Deal, and Y. Chen. 2010. Adaptive choicebased conjoint analysis: A new patient-centered approach to the assessment of health service preferences. Patient 3:257-273.

Drake, M. A., P. D. Gerard, V. D. Truong, and C. R. Daubert. 1999. Relationship between instrumental and sensory measures of cheese texture. J. Texture Stud. 30:451-476.

Drake, S. L., P. D. Gerard, and M. A. Drake. 2008. Consumer preferences for mild cheddar cheese flavors. J. Food Sci. 73:S449-S455.

Drake, S. L., K. Kopetcharat, and M. A. Drake. 2009. Comparison of two methods to explore consumer preference for cottage cheese. J. Dairy Sci. 92:5883-5897.

Engwall, H. P. 2015. Wisconsin Milk Marketing Board Predicts Consumer Cheese Trends for 2016. Wisconsin Milk Marketing Board. Accessed Nov. 21, 2017. http://www.wisconsindairy.org/Who-We -Are/mediaReleaseDetail/2015/12/22/wisconsin-milk-marketing -board-predicts-consumer-cheese-trends-for-2016.

Felix, S. 2009. Shred of truth. Canadian Grocer 123:40-42.

Foegeding, E. A. 2015. A natural opportunity. J. Food Sci. 80:iv.

Ganesan, B., K. Brown, D. A. Irish, C. Brothersen, and D. J. McMahon. 2014. Manufacture and sensory analysis of reduced- and low-sodium cheddar and mozzarella cheeses. J. Dairy Sci. 97:19701982.

Guinee, T. P., M. A. E. Auty, and M. A. Fenelon. 2000. The effect of fat content on the rheology, microstructure and heat-induced functional characteristics of cheddar cheese. Int. Dairy J. 10:277-288.

Harwood, W. S., and M. A. Drake. 2018. Identification and characterization of fluid milk consumer groups. J. Dairy Sci. 101:8860-8874.

Hein, K. A., S. R. Jaeger, B. T. Carr, and C. M. Delahunty. 2008. Comparison of five common acceptance and preference methods. Food Qual. Prefer. 19:651-661.

Hubbard, E. M., S. M. Jervis, and M. A. Drake. 2016. The effect of extrinsic attributes on liking of cottage cheese. J. Dairy Sci. 99:183-193.

Jervis, S. M., J. Ennis, and M. A. Drake. 2012. A comparison of choice based conjoint versus adaptive choice based conjoint in the evaluation of drivers of choice of sour cream. J. Sens. Stud. 27:451-462.

Jervis, S. M., M. G. Jervis, B. Guthrie, and M. A. Drake. 2014. The efficacy of using photographs to represent attributes of sliced sandwich bread in an adaptive choice-based conjoint. J. Sens. Stud. 29:64-73. 
Jo, Y., D. M. Benoist, A. Ameerally, and M. A. Drake. 2018. Sensory and chemical properties of Gouda cheese. J. Dairy Sci. 101:19671989.

Kano, N., N. Seraku, F. Takahashi, and S. Tsjui. 1984. Attractive quality and must-be quality. J. Jpn. Soc. Quality Control 14:147-156.

Kim, M. K., K. Lopetcharat, and M. A. Drake. 2013. Influence of packaging information on consumer liking of chocolate milk. J. Dairy Sci. 96:4843-4856.

Kumar, N., and J. B. Steenkamp. 2007. Competing on price with traditional private labels. Chapter 2 in Private Label Strategy: How to Meet the Store Brand Challenge. Harvard Business School Press, Boston, MA.

Lillestøl, J. 1991. Multivariate statistical methods for quality creation: A review. Total Qual. Manag. Bus. 2:291-304.

Louviere, J. J., and G. G. Woodworth. 1990. Best-worst scaling: A model for largest difference judgments. Working Paper, Department of Marketing and Economic Analysis, University of Alberta, Canada.

Lynch, J. G. 1985. Uniqueness issues in the decompositional modeling of multi-attribute overall evaluations: An information integration perspective. J. Mark. Res. 22:1-19.

McLean, K. G., D. Hanson, S. Jervis, and M. A. Drake. 2017. Consumer perception of retail pork bacon attributes using adaptive choice conjoint analysis and maximum differential scaling. J. Food Sci. 82:2659-2668.

Mintel Group Ltd. 2018. Executive summary - Cheese - US. Accessed May 17, 2019. http://academic.mintel.com/display/916686.

Moskowitz, H. R., J. H. Beckley, and A. V. A. Resurreccion. 2012. Understanding consumers' and customers' needs - the growth engine. Chapter 3, pages 41-82 in Sensory and Consumer Research in Food Product Design and Development. 2nd ed. Blackwell Publishing Professional, Ames, IA.

Murray, J. M., and C. M. Delahunty. 2000. Mapping consumer preference for the sensory and packaging attributes of Cheddar cheese. Food Qual. Prefer. 11:419-435.

Nestrud, M. A., and H. T. Lawless. 2008. Perceptual mapping of citrus juices using projective mapping and profiling data from culinary professionals and consumers. Food Qual. Prefer. 19:431-438.

Ni, H., and S. Guansekaran. 2004. Image processing algorithm for cheese shred evaluation. J. Food Eng. 61:37-45.

Oltman, A. E., S. M. Jervis, and M. A. Drake. 2014. Consumer attitudes and preferences for fresh market tomatoes. J. Food Sci. 79:S2091-S2097.

Oltman, A. E., K. Lopetcharat, E. Bastian, and M. A. Drake. 2015. Identifying key attributes for protein beverages. J. Food Sci. 80:S1383-S1390

Orme, B. K. 2014. How conjoint analysis works. Chapter 2, pages 7-18 in Getting Started with Conjoint Analysis. 3rd ed. Research Publishers LLC, Glendale, CA.

Partridge, J. 2009. Cheddar and cheddar-type cheese. Chapter 9, pages 225-270 in The Sensory Evaluation of Dairy Products. Springer, New York, NY.

Raz, C., D. Piper, R. Haller, H. Nicod, N. Dusart, and A. Giboreau. 2008. From sensory marketing to sensory design: How to drive formulation using consumers' input. Food Qual. Prefer. 19:719-726.
Riviere, P., R. Monrozier, M. Rogeaux, J. Pages, and G. Saporta. 2006. Adaptive preference target: Contribution of Kano's model of satisfaction for an optimized preference analysis using a sequential consumer test. Food Qual. Prefer. 17:572-581.

Risvik, E., J. A. McEwan, J. S. Colwill, R. Rogers, and D. H. Lyon. 1994. Projective mapping: A tool for sensory analysis and consumer research. Food Qual. Prefer. 5:268-269.

Rogers, N. R., M. A. Drake, C. R. Daubert, D. J. McMahon, T. K. Bletsch, and E. A. Foegeding. 2009. The effect of aging on lowfat, reduced-fat, and full-fat Cheddar cheese texture. J. Dairy Sci. 92:4756-4772.

Saltmarsh, M. 2015. Recent trends in the use of food additives in the United Kingdom. J. Sci. Food Agric. 95:649-652.

Savidan, C. H., and C. Morris. 2015. Panelists' performances and strategies in paper-based and computer-based projective mapping. J. Sens. Stud. 30:145-155.

Serrano, J., G. Velazquez, K. Lopetcharat, J. A. Ramirez, and J. A. Torres. 2004. Effect of moderate pressure treatments on microstructure, texture, and sensory properties of stirred-curd cheddar shreds. J. Dairy Sci. 87:3172-3182.

Serrano, J., G. Velazquez, K. Lopetcharat, J. A. Ramirez, and J. A. Torres. 2005. Moderately high hydrostatic pressure processing to reduce production costs of shredded cheese: Microstructure, texture, and sensory properties of shredded milled curd cheddar. J. Food Sci. 70:S286-S293.

Singh, S. 2006. Impact of color on marketing. Manage. Decis. 44:783789.

Singh, T. K., M. A. Drake, and K. R. Cadwallader. 2003. Flavor of cheddar cheese: A chemical and sensory perspective. Comp. Rev. Food Sci. Food Safety 2:166-189.

Solheim, R., and H. T. Lawless. 1996. Consumer purchase probability affected by attitude towards low-fat foods, liking, private body consciousness and information on fat and price. Food Qual. Prefer. 7:137-143.

Swientek, B. 2017. Innovative products tap clean label trend. Food Technol. 71:64-65.

Tarver, T. 2017. Defining the humane treatment of food animals. Food Technol. 71:17-25.

Thompson, J. L., P. D. Gerard, and M. A. Drake. 2007a. Chocolate milk and the Hispanic consumer. J. Food Sci. 72:S666-S675.

Thompson, J. L., K. Lopetcharat, and M. A. Drake. 2007b. Preferences for commercial strawberry drinkable yogurts among African American, Caucasian, and Hispanic consumers in the United States. J. Dairy Sci. 90:4974-4987.

Wadhwani, R., and D. J. McMahon. 2012. Color of low-fat cheese influences flavor perception and consumer liking. J. Dairy Sci 95:2336-2346.

Young, N. D., M. A. Drake, K. Lopetcharat, and M. R. McDaniel. 2004. Preference mapping of cheddar cheese with varying maturity levels. J. Dairy Sci. 87:11-19. 